\title{
Effects of temperature and salinity stress on DNA methylation in a highly invasive marine invertebrate, the colonial ascidian Didemnum vexillum
}

\author{
Nicola A Hawes ${ }^{\text {Corresp., }}{ }^{1,2}$, Louis A Tremblay ${ }^{2,3}$, Xavier Pochon ${ }^{1,2}$, Brendon Dunphy ${ }^{1,3}$, Andrew E Fidler ${ }^{1}$, \\ Kirsty F Smith ${ }^{2}$ \\ 1 Institute of Marine Science, University of Auckland, Auckland, New Zealand \\ 2 Cawthron Institute, Nelson, New Zealand \\ ${ }^{3}$ School of Biological Sciences, University of Auckland, Auckland, New Zealand \\ Corresponding Author: Nicola A Hawes \\ Email address: Nicola.hawes@cawthron.org.nz
}

Environmentally induced epigenetic changes may contribute to phenotypic plasticity, increase adaptive potential in changing environments, and play a key role in the establishment and spread of invasive species in new habitats. In this study, we used Methylation Sensitive Amplified Length Polymorphism (MS-AFLP) to assess environmentally induced DNA methylation changes in a globally invasive clonal ascidian, Didemnum vexillum. We tested the effect of increasing temperature $\left(19,25\right.$ and $\left.27^{\circ} \mathrm{C}\right)$ and decreasing salinity $(34,32,30,28$ and 26 practical salinity units (PSU) on global DNA methylation, growth and survival rates. Exposure to $27^{\circ} \mathrm{C}$ resulted in significant changes in DNA methylation over time, while there were no significant changes in non-methylated loci (representing genetic variation). Growth also decreased in colonies exposed to high temperatures, suggesting they were under thermal stress. In contrast, no differences in growth or DNA methylation patterns were observed in colonies exposed to a decreasing salinity gradient, potentially due to prior adaptation to conditions experienced at the site of collection. The results of this study show that environmental stress can induce significant global DNA methylation changes in an invasive marine invertebrate on very rapid timescales, and that this response varies depending on the type, magnitude, and duration of the stressor. Changes in genomic DNA methylation and the rate of growth may act to 'buy survival time' until conditions improve, and determine the distribution limits of this globally invasive species. 


\section{Effects of temperature and salinity stress on DNA methylation in a}

\section{2 highly invasive marine invertebrate, the colonial ascidian Didemnum}

3 vexillum

\section{4}

5

6

7

8 Nicola A. Hawes ${ }^{1,2}$, Louis A. Tremblay ${ }^{1,3}$, Xavier Pochon ${ }^{1,2}$, Brendon Dunphy ${ }^{2,3}$, Andrew E.

$9 \quad$ Fidler $^{2}$, Kirsty F. Smith ${ }^{1}$

10

${ }^{1}$ Cawthron Institute, 98 Halifax Street East, Nelson 7010, New Zealand

${ }^{2}$ Institute of Marine Science, University of Auckland, Private Bag 92019, Auckland 1142, New

13 Zealand

${ }^{3}$ School of Biological Sciences, University of Auckland, Private Bag 92019, Auckland 1142, New

15 Zealand

16

Corresponding Author:

22 Nicola Hawes, Email address: nicola.hawes@cawthron.org.nz 


\section{Abstract}

24 Environmentally induced epigenetic changes may contribute to phenotypic plasticity, increase adaptive potential in changing environments, and play a key role in the establishment and spread of invasive species in new habitats. In this study, we used Methylation-Sensitive Amplified Fragment Length Polymorphism (MS-AFLP) to assess environmentally induced DNA methylation changes in a globally invasive colonial ascidian, Didemnum vexillum. We tested the effect of increasing temperature $\left(19,25\right.$ and $\left.27^{\circ} \mathrm{C}\right)$ and decreasing salinity $(34,32,30,28$ and 26 practical salinity units (PSU)) on global DNA methylation, growth and survival rates. After three days of exposure to elevated temperature, significant DNA methylation differences were observed between treatments. Exposure to $27^{\circ} \mathrm{C}$ resulted in changes in DNA methylation over time, while there were no significant changes in non-methylated loci (representing genetic variation). Growth also decreased in colonies exposed to high temperatures, suggesting they were under thermal stress. In contrast, no differences in growth or DNA methylation patterns were observed in colonies exposed to a decreasing salinity gradient, potentially due to prior adaptation to conditions experienced at the site of collection. The results of this study show that environmental stress can induce significant global DNA methylation changes in an invasive marine invertebrate on very rapid timescales, and that this response varies depending on the type, magnitude, and duration of the stressor. Changes in genomic DNA methylation and the rate of growth may act to 'buy survival time' until conditions improve, and determine the distribution limits of this globally invasive species. 
46

47

48

\section{Introduction}

Species invasions, climate change, habitat fragmentation and environmental degradation are altering ecosystems and threatening biodiversity (Leadley 2010). A key question in evolutionary biology is whether species will be able to adapt in response to these human-driven environmental changes (Visser 2008). Biological invasions can provide a unique model to investigate adaptation and evolution within short timescales, as introduced species must rapidly adapt to new habitats (Allendorf \& Lundquist 2003; Sakai et al. 2001). It has been suggested that epigenetic mechanisms could play a critical role in environmental adaptation, and may be particularly important for the success of invasive species (Estoup et al. 2016; Pérez et al. 2006; Prentis et al. 2008). Recently introduced populations frequently have reduced genetic diversity (e.g., genetic bottlenecks and founder effects) (Dlugosch \& Parker 2008), which is thought to constrain the colonisation potential of a species (e.g., Crawford \& Whitney 2010). Despite this, invasive species can still be highly successful in their new environments, and often outcompete locally adapted native species (Allendorf \& Lundquist 2003). By increasing both phenotypic plasticity and heritable variation, epigenetic changes might allow invasive species to quickly respond to environmental challenges. However, the role that epigenetic mechanisms play during the process of invasion is only beginning to be understood (Hawes et al. 2018) and, for many species, the effect of environmetnal stressors on DNA methylation is unknown.

Epigenetic modifications have been shown to respond to environmental cues and, in some cases, be associated with significant phenotypic change (Dias \& Ressler 2014; Kucharski et al. 2008; Waterland \& Jirtle 2003). Epigenetic mechanisms are diverse and interactive (e.g., DNA methylation, histone modifications, small RNAs), but all alter gene expression without the 
69 requirement for changes in the underlying DNA nucleotide sequences (Bossdorf et al. 2008).

70 Currently the most studied epigenetic mechanism is the methylation of cytosine nucleotides to

71 form 5 methyl-cytosine (DNA methylation). DNA methylation is common in eukaryotes, and

72 there are a range of methods for its detection and quantification (Plongthongkum et al. 2014).

73 One such method, Methylation-Sensitive Amplified Fragment Length Polymorphism (MS-

74 AFLP), allows for cost-effective screening of variation in global DNA methylation, without the

75 requirement for a reference genome (Reyna-Lopez et al. 1997). The MS-AFLP technique enables

76 epigenetic research in non-model organisms and can provide a first look at DNA methylation-

77 environment interactions, which may underlie adaptive plasticity. Interest in the ecological relevance of DNA methylation in non-model organisms is growing, and marine invertebrates have been identified as an emerging taxonomic group for studies of ecological epigenetics, particularly in the context of environmental change (Hofmann 2017). Despite this, few studies have investigated environmentally induced epigenetic changes in marine invertebrates (Marsh et al. 2016; Marsh \& Pasqualone 2014; Putnam et al. 2016), and the role of epigenetic mechanisms in the success of marine invertebrate invaders is only beginning to be explored (Ardura et al. 2017; Huang et al. 2017; Pu \& Zhan 2017).

Of the marine invertebrates, colonial ascidians stand out as model species to study both environmentally induced DNA methylation changes (Hawes et al. 2018) and invasion success (Zhan et al. 2015). Colonial ascidians (phylum Chordata) are common marine invaders worldwide, particularly in habitats perturbed by human activities, e.g., marinas, ports, aquaculture structures (Lambert 2001). Due to the considerable ecological and economic damage caused by ascidian invasions, they have become a prominent study species in the field of 
92 invasion biology (Zhan et al. 2015). Ascidians can thrive in a variety of environmental

93 conditions, and display unique biological characteristics, including a broad tolerance to common

94 environmental stressors such as temperature and salinity (Rocha et al. 2017). Additionally, the

95 germ-cell lineages of colonial ascidians originate from somatic-cell lineages, contrasting with the

96 germ-cell lineage sequestration found in vertebrate Chordates (Rosner et al. 2009). Having no

97 true germ-cell lineage sequestration increases the likelihood that stress-induced epigenetic

98 modifications induced in somatic cells can be passed on to gametes (Verhoeven \& Preite 2014).

99 Finally, asexual reproduction (by budding) leads to colonies of genetically identical individual

100 animals (termed zooids) that all share the same DNA nucleotide sequences (genotype). Clonal

101 reproduction allows for genetically identical replicates across environment stress treatments, and

102 repeated sampling of the same individual at multiple time-points. This reduces the confounding

103 effects of genetic variation that frequently complicate epigenetic studies of non-clonal organisms

104 (Douhovnikoff \& Dodd 2015; Verhoeven \& Preite 2014).

Invasive populations of the colonial ascidian, Didemnum vexillum Kott, 2002 have extremely low levels of genetic diversity compared to populations within its native range (Stefaniak et al. 2012). Despite this, D. vexillum is extremely successful where it has invaded (Beveridge et al. 2011; Cohen et al. 2011; Griffith et al. 2009; Hitchin 2012; Lambert et al. 2009; Tagliapietra et al. 2012), often forming large colonies that smother other marine invertebrates, including commercial aquaculture species (Fletcher et al. 2013b). We used MS-AFLP to determine whether a) DNA methylation is present in the genome of $D$. vexillum, and b) if genome-wide DNA methylation patterns in $D$. vexillum change in response to two prominent types of

114 environmental stress: temperature and salinity. Temperature and salinity are often reported as the 
115 most important environmental determinants controlling the distribution of marine species, and

116 these two parameters have been used repeatedly when studying the tolerance of ascidians to

117 environmental stress (Dybern 1967; Gröner et al. 2011; Renborg et al. 2014; Serafini et al. 2011;

118 Zerebecki \& Sorte 2011). Furthermore, extreme climatic events such as precipitation events and

119 heatwaves are expected to increase in frequency in the near future (IPCC 2014), making it

120 increasingly important to evaluate the response and resilience of marine invertebrates to thermal 121 and osmotic stress.

\section{Materials and Methods}

Sample collection and establishment of experimental colonies

125 Colonies of $D$. vexillum were collected from the Nelson Marina (South Island, New Zealand; $\left.41^{\circ} 15^{\prime} 38^{\prime \prime} \mathrm{S}, 173^{\circ} 16^{\prime} 54^{\prime \prime} \mathrm{E}\right)$ in April 2016. At the time of collection, the water temperature was $19^{\circ} \mathrm{C}$ and the salinity was 33 PSU. Colonies were gently removed from wharf pilings and immediately placed in labelled $2 \mathrm{~L}$ plastic containers filled with ambient seawater for transport to the Cawthron Institute (less than 5 minutes commute). Attempts were made to remove whole colonies that were free from debris, but as the colonies were mostly small and growing flat over piles covered in other fouling, colonies often broke apart during removal. We treated these fragments as one colony for the following experiments but it is possible that it was two or more colonies growing in close proximity. After arrival at the laboratory, the colonies were gently

134 cleaned with seawater to remove mud, silt and other organisms, and approximately equal sized

136 on glass slides and gently wrapped with cotton thread to encourage attachment (Rinkevich \&

137 Fidler 2014). Glass slides were inserted into slide holders and placed in pre-conditioned $40 \mathrm{~L}$ 
138 glass aquaria in ambient, control conditions $\left(19^{\circ} \mathrm{C}, 34 \mathrm{PSU}\right)$ for one week to allow attachment to 139 occur. During this acclimation period, colonies were fed $1.6 \times 10^{8}$ cells. $\mathrm{L}^{-1}$ of cultured algae

140 (Isochrysis galbana) every second day. Following attachment, the cotton was removed and the

141 colony fragments were randomly allocated (Temperature: $n=9$, Salinity: $n=15$ ) to pre-

142 conditioned treatment tanks $(n=$ three tanks per treatment, one colony fragment per treatment

143 tank). All treatment tanks were maintained at $19^{\circ} \mathrm{C}$ and $34 \mathrm{PSU}$ for a further two weeks

144 acclimation time prior to beginning the experiments.

Experimental system

147 Seawater for the experiments was collected from Tasman Bay, Nelson $\left(41^{\circ} 11^{\prime} 29.2^{\prime \prime S}\right.$

$148173^{\circ} 21^{\prime} 01.9^{\prime \prime E}$ ), passed through three filters (pore size 50, 5, and $0.35 \mu \mathrm{m}$ ) and ultraviolet light

149 treated. Each tank was filled with freshly collected seawater at the start of the experiment, and

150 five L water exchanges were done daily throughout the duration of the experiment with pre-

151 heated or reduced salinity seawater. Each day following water exchange, colonies were fed a diet

152 of $1.6 \times 10^{8}$ cells.L $L^{-1}$ of $I$. galbana. To prevent stratification, mixing in experimental tanks was

153 ensured by gentle aeration using air stones. Experimental tanks were exposed to a 14:10 hour

154 light:dark cycle to mimic summer conditions. Water temperatures were maintained using

155 thermostatically regulated aquarium heaters (EHEIM JAIGER 100W, Deizisau, Germany) and

156 salinity treatments were achieved and maintained by the addition of reverse osmosis (RO) water

157 to seawater. Water temperature and salinity were measured twice daily using hand-held probes to 158 ensure stable treatment conditions were maintained $\pm 0.5^{\circ} \mathrm{C}$ or 0.5 PSU (YSI Professional Plus, 159 YSI Incorporated, Yellow Springs Ohio, USA). After two weeks of acclimation, tissue samples 160 were collected from all colonies for MS-AFLP analyses (Time 0; T0). Temperatures were then 
161 increased by $1{ }^{\circ} \mathrm{C}$ per day for temperature treatments, and salinity was reduced by 1 PSU per day

162 for the salinity treatments until, after eight days, all treatment conditions were reached.

163 Treatments were as follows: temperature $=19($ Control $), 25$, and $27^{\circ} \mathrm{C}$ and salinity $=34$

164 (Control), 32, 30, 28, and 26 PSU. Temperature and salinity experiments were run in parallel.

165 Tissue samples were taken at day eight for MS-AFLP analyses (Time 1; T1). Colony fragments

166 were then maintained in experimental treatments for a further three days (day 11), at which time

167 final tissue samples were taken for MS-AFLP analyses (Time 2; T2).

Sampling protocol

170 Prior to tissue collection, colonies were not fed for 16 hours to minimise contamination by feed 171 microalgae. To collect tissue for MS-AFLP analyses, small (c. $5 \mathrm{~mm}$ x $5 \mathrm{~mm}$ ) samples were 172 taken from each colony using a sterile razorblade. Tissue samples were preserved in $95 \%$

173 ethanol, which was refreshed once before storage at $-20^{\circ} \mathrm{C}$ until processing. Pre- and post-tissue 174 sampling, photos were taken for growth rate calculations. Colony growth rates (quantified by 175 changes in colony surface-area over time) were measured using Image J $1.48 \mathrm{v}$ software 176 (Schneider et al. 2012). The survival of colonies was also monitored at the time of sampling by 177 assessments of colony health, including zooid integrity, colour and texture of the colony, build178 up of detritus and dead tissue. Throughout the experiment, all colonies were transported, sampled 179 and photographed while submerged in trays of temperature and salinity adjusted seawater to 180 minimise handling stress. 
182

183

184

185

186

187

188

189

190

191

192

193

194

195

196

197

198

199

200

201

202

203

204

MS-AFLP analysis

To assess whole genome DNA methylation patterns, DNA was extracted using G-spin Total DNA extraction kits (animal tissue protocol; Intron, Gyeonggi-do, South Korea). Following DNA extraction, in parallel reactions ( $25 \mu \mathrm{L}$ final reaction volume), $500 \mathrm{ng}$ of DNA was digested with $10 \mathrm{U}$ of each restriction enzyme (MspI and EcoRI or HpaII and EcoRI; New England BioLabs, Ipswich, MA, USA) and 10X CutSmart Buffer (England BioLabs), and incubated at $37^{\circ} \mathrm{C}$ for 2 hours followed by $80^{\circ} \mathrm{C}$ for $20 \mathrm{~min}$ to inactivate the enzymes. The digested DNA were ligated in a final volume of $20 \mu \mathrm{L}$ containing $1 \mathrm{U}$ of T4 DNA ligase (New England BioLabs), 10X ligase buffer, $250 \mathrm{nM}$ of EcoRI adapter, and $2.5 \mu \mathrm{M}$ of MspI or HpaII adaptor for 3 hours at $37^{\circ} \mathrm{C}$. Table 1 presents a list of all adapter and primer sequences used for the MS-AFLP protocol. Pre-selective polymerase chain reaction (PCR) was performed in a total volume of $20 \mu \mathrm{L}$ using $8 \mu \mathrm{L}$ of ligated DNA, MyTaq ${ }^{\mathrm{TM}} 2 \mathrm{X}$ PCR master mix (Bioline, MA, USA), and $500 \mathrm{nM}$ of each pre-selective primer. Thermocycling conditions were 20 cycles of: $94^{\circ} \mathrm{C}$ for $30 \mathrm{~s}, 56^{\circ} \mathrm{C}$ for $60 \mathrm{~s}$, and $72^{\circ} \mathrm{C}$ for $60 \mathrm{~s}$. Selective PCR was performed using four EcoRI and MspI/HpaII primer combinations in a final volume of $20 \mu \mathrm{L}$ using $1 \mu \mathrm{L}$ of pre-selective PCR product, MyTaq ${ }^{\mathrm{TM}}$ 2X PCR master mix (Bioline, MA, USA), and $500 \mathrm{nM}$ of each combination of forward and reverse selective primers. Thermocycling conditions were 1 cycle of: $94^{\circ} \mathrm{C}$ for 2 min; 10 cycles of $94^{\circ} \mathrm{C}$ for $30 \mathrm{~s}, 65^{\circ} \mathrm{C}$ for $30 \mathrm{~s}$ (decreasing $1^{\circ} \mathrm{C}$ per cycle), and $72^{\circ} \mathrm{C}$ for $60 \mathrm{~s}$; and 30 cycles of $94^{\circ} \mathrm{C}$ for $30 \mathrm{~s}, 56^{\circ} \mathrm{C}$ for $30 \mathrm{~s}$, and $72^{\circ} \mathrm{C}$ for $60 \mathrm{~s}$; and a hold cycle of $72^{\circ} \mathrm{C}$ for 30 min. The resulting selective PCR product was diluted 1:5 with sterile distilled water and analysed using an ABI 3130 capillary sequencer (Applied Biosystems, Foster City, CA, USA) with internal size standards (GS600LIZ) by an external contractor (Genetic Analysis Services, University of Otago, Dunedin, New Zealand). 
Data analysis

207

208

209

210

211

212

213

214

215

216

217

218

219

220

221

222

223

224

225

226

227

PEAKSCANNER software (Applied Biosystems, Foster City, CA, USA) was used to assign the MS-AFLP fragments peak height and size. To determine the parameters for subsequent analysis, the MS-AFLP procedure described above was first repeated three times for one individual sample. The following settings were associated with the lowest error rate between replicates and were applied to the msap analysis (Pérez-Figueroa 2013) described below. Error rate per primer, 0.07; analysis range, 50 - 500 base pairs (bp); minimum peak height, 1200 relative fluorescence units. Peak presence/absence data corresponding to HpaII and MspI fragments was then converted to a binary matrix (presence $=1$, absence $=0$ ), so that the methylation state of each restriction site could be identified. MS-AFLP profiles were assessed using the R package msap $\mathrm{v}$. 1.1.8 (Pérez-Figueroa 2013). The msap package determines whether individual fragments (loci) are methylated (MSL) by analysing the contents of the binary matrix, and comparing differences representing the differential sensitivities of HpaII and MspI to cytosine methylation (Table 2). From this, DNA methylation profiles of control and experimental samples were assessed by means of principal coordinate analyses (PCoA) followed by analyses of molecular variance (AMOVA) (Excoffier et al. 1992). Colony growth rates (mean growth per day, $\mathrm{mm} \pm 1$ s.e.) were assessed using standard ANOVA and post-hoc pairwise comparisons were made using Tukey's honest significance difference (HSD) test.

\section{Results}

\section{Temperature stress experiments}

\section{Growth rates}


228 All colonies survived elevated temperature exposure, and colony growth rates (Figure 1) were

229 significantly different between treatments (single level ANOVA, $F(2,6)=7.82, p=0.0213$;

230 Table S1). Post hoc comparisons using Tukey HSD indicated that growth per day was

231 significantly reduced when colonies were exposed to $27^{\circ} \mathrm{C}$ compared to colonies grown at $19^{\circ} \mathrm{C}$

232 (Diff $=-61.43, p=0.01$; Table S2, Figure 1). Growth was not significantly different between

233 colonies exposed to $25^{\circ} \mathrm{C}$ and $27^{\circ} \mathrm{C}$ or $19^{\circ} \mathrm{C}$ and at $25^{\circ} \mathrm{C}$.

234

Whole genome DNA methylation patterns (MS-AFLP)

236 Using four primer combinations, 1157 fragments (loci) were produced and analysed. At

237 sampling time zero (T0), prior to temperature treatment exposure, 586 of the 1157 loci were

238 MSL, of which 178 were polymorphic (30\%). There were no significant differences in DNA

239 methylation (Figure 2A) (MSL, $\phi_{\mathrm{ST}}=-0.04981, p=0.7093$, single level AMOVA; Table S3)

240 between treatment groups. Following eight days of gradual temperature increase, (T1), of the

2411157 loci analysed 613 were MSL, of which 172 were polymorphic (28\%). There were still no

242 significant differences between DNA methylated (MSL) loci (Figure $2 \mathrm{~B})\left(\phi_{\mathrm{ST}}=0.05606, p=\right.$

243 0.2176, single level AMOVA; Table S3) between the three temperature treatments. However,

244 after three days of exposure to elevated temperature, of 1157 loci 600 were MSL, of which 201

245 were polymorphic (34\%) and statistically significant differences in DNA methylation were

246 evident between treatment groups (Figure 2C) $\left(\mathrm{MSL}, \phi_{\mathrm{ST}}=0.1585, p=0.0215\right.$, single level

247 AMOVA; Table S3). There were no significant global methylation changes between sampling

248 time points in colonies held at $19^{\circ} \mathrm{C}$ (Figure 2D) (MSL, $\phi_{\mathrm{ST}}=-0.0212, p=0.6019$, single level

249 AMOVA; Table S5) or $25^{\circ} \mathrm{C}($ Figure $2 \mathrm{E})\left(\mathrm{MSL}, \phi_{\mathrm{ST}}=-0.01373, p=0.5637\right.$, single level

250 AMOVA; Table S4). In contrast, there were significant DNA methylation changes following 
251 exposure to $27^{\circ} \mathrm{C}$ (Figure $2 \mathrm{~F}$ ) $\left(\mathrm{MSL}, \phi_{\mathrm{ST}}=0.1727, p=0.0223\right.$, single-level AMOVA; Table

252 S4). Variation between individuals was also reduced in the $27^{\circ} \mathrm{C}$ treatment group, with DNA 253 methylation patterns becoming more similar, as visualised by the reduced spread of samples

254 around the centroid in the PCoA for each temperature (Figure 2C).

255

256 Salinity stress experiments

257 Growth rates

258 Akin to the temperature treatment, all colonies survived decreased salinity exposure. Colony 259 growth rates were not significantly different between treatment groups (Figure 3) (single level 260 ANOVA, $F(4,10)=2.066, p=0.161 ;$ Table S5).

261

262

Whole genome DNA methylation patterns (MS-AFLP)

263 Using four primer combinations, 1050 loci were produced and analysed. At sampling time zero

264 (T0), prior to differential salinity exposure, of these, 626 were methylation sensitive loci (MSL), 265 of which 169 were polymorphic (27\%). There were no significant differences in DNA

266 methylation between treatment groups (Figure 4A) $\left(\mathrm{MSL}, \phi_{\mathrm{ST}}=-0.05023, p=0.686\right.$, single level

267 AMOVA; Table S6). Following the gradual salinity decrease, at time one (T1), of 1050 loci 654

268 were MSL, of which 173 were polymorphic (26\%). There were no significant differences in

269 DNA methylation (Figure 4B) $\left(\mathrm{MSL}, \phi_{\mathrm{ST}}=0.02674, p=0.3518\right.$; single level AMOVA; Table

270 S6), between salinity treatments. After three days of exposure to elevated salinity, of 1050 loci,

271682 were MSL, of which 95 were polymorphic (14\%). Non-significant differences in DNA

272 methylation remained (Figure 4C) $\left(\mathrm{MSL}, \phi_{\mathrm{ST}}=-0.06389, p=0.8328\right.$, single level AMOVA). 
273 There were no significant methylation differences (Table S7) in any of the salinity treatments

274 over time (Figure 4D, E, F, G H).

275

276 Discussion

277 Changes in DNA methylation may be one of the mechanisms by which invasive species can

278 rapidly adapt to new environments. However, for many species, the responsiveness of DNA

279 methylation to environmental challenges has not yet been tested. Our results indicate that

280 environmental stressors can induce significant global DNA methylation changes in an invasive

281 marine invertebrate on very rapid timescales, and that this response varies depending on the type,

282 magnitude, and duration of the stressor. After three days of exposure to elevated temperature,

283 significant changes in whole-genome patterns of DNA methylation had occurred in D. vexillum

284 colonies held at $27^{\circ} \mathrm{C}$. In contrast, DNA methylation patterns in colonies exposed to $25^{\circ} \mathrm{C}$ and

$28519^{\circ} \mathrm{C}$ did not change significantly over time. It is yet to be tested if significant changes would be

286 observed at $25^{\circ} \mathrm{C}$ if the duration of exposure was extended, but our results provide the first

287 indication of methylation divergence with increasing temperature, and this effect may increase

288 with time. In contrast, we did not find any significant DNA methylation changes in response to

289 the salinity treatments used in this study.

290

291

Didemnum vexillum is a subtidal species and can tolerate severe, short-term declines in salinity,

292 but extended periods of low-salinity stress lead to mortality (Gröner et al. 2011; Rocha et al.

293 2017) and ascidians are rarely found in salinities lower than 25 PSU (Lambert 2005). Based on

294 the above, we selected five salinity treatments: 34 PSU (within the upper range at collection

295 site), 32 PSU (within the middle range at collection site), 30 PSU (within the lower range at the 
296 collection site), 28 PSU (within the lower global range) and 26 PSU (colonies are rarely found

297 below this level globally). However, at the colony collection site for this study (the Nelson

298 marina), salinity frequently drops below 26 PSU (Atalah 2017). The Nelson marina is located

299 within $1.5 \mathrm{~km}$ of a river mouth, and salinity drops are likely associated with rain events (Fletcher

300 et al. 2013a). The lack of response of genomic DNA methylation to changes in salinity suggests

301 that $D$. vexillum in the Nelson marina may already be adapted to a lower salinity environment

302 than was assessed in this experiment. This result is supported by the positive growth of colonies

303 in all salinity treatments and a lack of negative health indicators, an indication that colonies were

304 not experiencing significant stress. However, non-significant global methylation changes do not

305 necessarily demonstrate that important DNA methylation changes are not occurring. Locus

306 specific methylation differences have been associated with environmental differences in

307 temperature and salinity in solitary ascidians (Pu \& Zhan 2017), and MS-AFLP results can be

308 difficult to interpret due to changes in many genes at once.

310 One other study has experimentally investigated the effect of environmental stress on DNA methylation in an invasive marine invertebrate, and found very rapid ( $<3$ hours) global DNA methylation differences in response to low salinity stress, but these differences had disappeared within 48 hours (Huang et al. 2017). In this study, solitary ascidians (Ciona savignyi), were exposed to a lower salinity than the present study (20 PSU), with no gradual decrease allowing acclimation time, and all individuals died prior to the final sampling time point (120 hours) (Huang et al. 2017). Studies of solitary ascidians have shown salinity exposure can induce a strong behavioural and physiological response in the first 48 hours of severe osmotic stress, such as siphon closure and the excretion of intracellular osmolytes (Toop \& Wheatly 1993), which 
319 might be associated with such rapid, global DNA methylation changes. This may be a good

320 strategy for surviving short-term non-optimal salinity events, such severe storms or transport

321 through low salinity waters (Rocha et al. 2017), but prolonged stress will likely lead to mortality.

322 Nonetheless, this response demonstrates the potential for genome-wide methylation changes in

323 response to salinity stress.

324

Didemnum vexillum is a cool water temperate species found in a wide range of temperatures,

326 from $<0->24^{\circ} \mathrm{C}$ (Bullard et al. 2007). Optimal temperature for growth appears to be between

$32714^{\circ} \mathrm{C}$ and $20^{\circ} \mathrm{C}$. Based on this, we selected three temperature treatments: $19^{\circ} \mathrm{C}$ (within the

328 temperature range of $D$. vexillum colonies at the collection site, and the optimal range for $D$.

329 vexillum globally), $25^{\circ} \mathrm{C}$ (just outside the temperature range at the collection site, and near the

330 upper limit globally), and $27^{\circ} \mathrm{C}\left(+3^{\circ} \mathrm{C}\right.$ of the upper limit at the collection site, but within global

331 climate change predictions for the year 2100; IPCC 2014). Temperatures at the collection site in

332 the Nelson marina typically range from $9^{\circ} \mathrm{C}-10^{\circ} \mathrm{C}$ (winter minima) and $22^{\circ} \mathrm{C}-23^{\circ} \mathrm{C}$ (summer

333 maxima) (Fletcher et al. 2013a). The D. vexillum colonies used in this study would rarely

334 experience temperatures of $25^{\circ} \mathrm{C}$ or greater. The significant global DNA methylation changes

335 observed in colonies held at $27^{\circ} \mathrm{C}$, after just three days exposure, is indicative of a dramatic

336 response to thermal stress. A conclusion that is further supported by the significant negative

337 growth of colonies held at these elevated temperatures compared to controls. Alterations to

338 energetic balance (e.g., decreased growth/reproduction, switching to anaerobic metabolism) and

339 protein expression profiles (e.g., upregulation of heat shock chaperones), are well known and

340 energetically costly processes undertaken by invertebrates in response to thermal stress

341 (Sokolova et al. 2012). Such responses can act to 'buy survival time' until conditions improve, 
342 and determine species distribution limits. This strategy may allow colonial ascidians to invade

343 new areas. For example, the recent expansion of $D$. vexillum from temperate regions into the

344 warmer, subtropical waters of the Mediterranean Sea $\left(8-28^{\circ} \mathrm{C}\right)$ provides evidence of the

345 remarkable capacity of $D$. vexillum to adapt to increasing temperatures (Ordóñez et al. 2015). In

346 temperate regions, maximum growth and reproduction in D. vexillum occurs during the warmer,

347 summer months, with regression of colony growth and size occurring during winter (Fletcher et

348 al. 2013a). In the Mediterranean, this cycle is reversed (Ordóñez et al. 2015). By growing and

349 reproducing in the winter months and regressing during the summer months, D. vexillum is able

350 to extend its introduced range towards warmer waters (Ordóñez et al. 2015).

352 The MS-AFLP technique does not provide any insight into the identification of genes which are 353 differentially methylated, so we are unable to demonstrate that any environmentally induced 354 changes to DNA methylation are associated with functional traits that could lead to adaptive 355 outcomes. However, correlative experiments have previously suggested a role for DNA methylation in adaptation to thermal stress, with natural populations of fish having higher levels

357 of methylation in polar and sub-Antarctic species compared to temperate/tropical species

358 (Varriale \& Bernardi 2006). Some natural populations of the solitary ascidian, Ciona robusta,

359 display significant DNA methylation differences in genes that can be correlated with

360 environmental differences in temperature and salinity ( $\mathrm{Pu} \&$ Zhan 2017). Furthermore,

361 experimental evidence for an adaptive response to temperature stress has been shown using an

362 Antarctic marine polychaete worm, Spiophanes tcherniai. In this species, large DNA methylation

363 shifts were observed after exposure to a $5.5^{\circ} \mathrm{C}$ temperature increase, and this shift was

364 accompanied by physiological adaptation, with respiration and metabolic rates returning to 
365 control levels in less than four weeks (Marsh \& Pasqualone 2014). Future studies utilising

366 techniques with base pair resolution (e.g., bisulphite sequencing) will provide detailed insights

367 into the location of methylation changes in specific genes associated with functional outcomes.

368 This type of technique would also benefit from the analysis of downstream biological pathways,

369 such as the analysis of gene expression and metabolomic profiling.

371 Conclusions

372 In this study, we demonstrate the responsiveness of DNA methylation following exposure to an

373 environmental gradient (temperature), which was correlated with phenotypic change (growth).

374 Furthermore, DNA methylation changes did not occur in colonies exposed to an environmental

375 gradient to which they may already be adapted (salinity). This is the first study to investigate

376 DNA methylation patterns in a colonial ascidian, specifically the highly invasive D. vexillum,

377 and adds to a growing body of evidence that DNA methylation plays a key role in the plasticity

378 of adaptive traits. Epigenetic changes may contribute not only to the success of invasive species,

379 but also to the adaptability of native species to changes within their environmental range. $D$.

380 vexillum is an excellent model organism for future research into epigenetic responses to

381 environmental stress. The responsiveness of DNA methylation to changes in the environment in

382 this species lends itself to future studies testing the stability and longevity of these changes, and

383 whether these changes can be associated with adaptive outcomes. Evidently, many key questions

384 remain unanswered, including whether differences in methylation persist over time? Does

385 tolerance for elevated temperature increase following exposure and, is tolerance associated with

386 a specific epigenetic modification? However, our study establishes a baseline understanding of

387 the role of DNA methylation in a globally invasive species. This unique study system provides a 
388 powerful framework for ecological epigenetic studies that could enhance our understanding of 389 adaptation to rapid environmental change.

390

391 Acknowledgements

392 We are grateful to Eric Goodwin (Cawthron) for help with R coding. Thank you to Achira 393 Amadoru (Nelson Marlborough Institute of Technology) for assistance with experiment 394 maintenance.

\section{References}

397

Allendorf FW, and Lundquist LL. 2003. Introduction: population biology, evolution, and control of invasive species. Conservation Biology 17:24-30.

Ardura A, Zaiko A, Morán P, Planes S, and Garcia-Vazquez E. 2017. Epigenetic signatures of invasive status in populations of marine invertebrates. Scientific Reports 7.

Atalah, Javier (2017): Nelson Marina, New Zealand: SST and salinity data. figshare. https://doi.org/10.6084/m9.figshare.5277025.v1.

Beveridge C, Cook E, Brunner L, MacLeod A, Black K, Brown C, and Manson F. 2011. Initial response to the invasive carpet sea squirt, Didemnum vexillum. Scotland Scottish Natural Heritage Commissioned Report 413:24.

Bossdorf O, Richards CL, and Pigliucci M. 2008. Epigenetics for ecologists. Ecology Letters $11: 106-115$.

Bullard SG, Lambert G, Carman MR, Byrnes J, Whitlatch RB, Ruiz G, Miller R, Harris L, Valentine PC, and Collie JS. 2007. The colonial ascidian Didemnum sp. A: current distribution, basic biology and potential threat to marine communities of the northeast 
411

412

413

414

415

416

417

418

419

420

421

422

423

424

425

426

427

428

429

430

431

and west coasts of North America. Journal of Experimental Marine Biology and Ecology 342:99-108.

Cohen CS, McCann L, Davis T, Shaw L, and Ruiz G. 2011. Discovery and significance of the colonial tunicate Didemnum vexillum in Alaska. Aquatic Invasions 6:263-271.

Crawford K, and Whitney K. 2010. Population genetic diversity influences colonization success. Molecular Ecology 19:1253-1263.

Douhovnikoff V, and Dodd RS. 2015. Epigenetics: a potential mechanism for clonal plant success. Plant Ecology 216:227-233.

Dias BG, and Ressler KJ. 2014. Parental olfactory experience influences behavior and neural structure in subsequent generations. Nature Neuroscience 17:89-96.

Dlugosch KM, and Parker IM. 2008. Founding events in species invasions: genetic variation, adaptive evolution, and the role of multiple introductions. Molecular Ecology 17:431449.

Dybern BI. 1967. The distribution and salinity tolerance of Ciona intestinalis (L.) f. typica with special reference to the waters around southern Scandinavia. Ophelia 4:207-226.

Estoup A, Ravigné V, Hufbauer R, Vitalis R, Gautier M, and Facon B. 2016. Is there a genetic paradox of biological invasion? Annual Review of Ecology Evolution and Systematics 47:51-72.

Excoffier L, Smouse PE, and Quattro JM. 1992. Analysis of molecular variance inferred from metric distances among DNA haplotypes: application to human mitochondrial DNA restriction data. Genetics 131:479-491. 
432 Fletcher LM, Forrest BM, Atalah J, and Bell JJ. 2013a. Reproductive seasonality of the invasive

433

434

435

436

437

438

439

440

441

442

443

444

445

446

447

448

449

450

451

452

453 ascidian Didemnum vexillum in New Zealand and implications for shellfish aquaculture. Aquaculture Environment Interactions 3:197-211.

Fletcher LM, Forrest BM, and Bell JJ. 2013b. Impacts of the invasive ascidian Didemnum vexillum on green-lipped mussel Perna canaliculus aquaculture in New Zealand. Aquaculture Environment Interactions 4:17-30.

Griffith K, Mowat S, Holt RH, Ramsay K, Bishop JD, Lambert G, and Jenkins SR. 2009. First records in Great Britain of the invasive colonial ascidian Didemnum vexillum Kott, 2002. Aquatic Invasions 4:581-590.

Gröner F, Lenz M, Wahl M, and Jenkins SR. 2011. Stress resistance in two colonial ascidians from the Irish Sea: The recent invader Didemnum vexillum is more tolerant to low salinity than the cosmopolitan Diplosoma listerianum. Journal of Experimental Marine Biology and Ecology 409:48-52.

Hawes NA, Fidler AE, Tremblay LA, Pochon X, Dunphy B and Smith KF. 2018. Understanding the role of DNA methylation in successful biological invasions - A review. Biological Invasions https://doi.org/10.1007/s10530-018-1703-6.

Hitchin B. 2012. New outbreak of Didemnum vexillum in North Kent: on stranger shores. Porcupine Marine Natural History Society Newsletter 31:43-48.

Hofmann G. 2017. Ecological Epigenetics in Marine Metazoans. Front. Mar Sci 4.

Huang X, Li S, Ni P, Gao Y, Jiang B, Zhou Z, and Zhan A. 2017. Rapid response to changing environments during biological invasions: DNA methylation perspectives. Molecular Ecology 26(23):6621-6633. 
454 IPCC, 2014: Climate Change 2014: Synthesis Report. Contribution of Working Groups I, II and 455 III to the Fifth Assessment Report of the Intergovernmental Panel on Climate Change

456

457

458

459

460

461

462

463

464

465

466

467

468

469

470

471

472

473

474

475

[Core Writing Team, R.K. Pachauri and L.A. Meyer (eds.)]. IPCC, Geneva, Switzerland, $151 \mathrm{pp}$.

Kucharski R, Maleszka J, Foret S, and Maleszka R. 2008. Nutritional control of reproductive status in honeybees via DNA methylation. Science 319:1827-1830.

Lambert G. 2001. A global overview of ascidian introductions and their possible impact on the endemic fauna. The biology of ascidians: Springer, 249-257.

Lambert G. 2005. Ecology and natural history of the protochordates. Canadian Journal of Zoology 83:34-50.

Lambert G, Locke A, and Carman M. 2009. Adventures of a sea squirt sleuth: unraveling the identity of Didemnum vexillum, a global ascidian invader. Aquatic Invasions 1:5-28.

Leadley P. 2010. Biodiversity scenarios: projections of 21st century change in biodiversity, and associated ecosystem services: a technical report for the global biodiversity outlook 3: UNEP/Earthprint.

Marsh AG, Hoadley KD, and Warner ME. 2016. Distribution of CpG Motifs in Upstream Gene Domains in a Reef Coral and Sea Anemone: Implications for Epigenetics in Cnidarians. PLOS ONE 11:e0150840.

Marsh AG, and Pasqualone AA. 2014. DNA methylation and temperature stress in an Antarctic polychaete, Spiophanes tcherniai. Frontiers in Physiology 5:173-181.

Ordóñez V, Pascual M, Fernández-Tejedor M, Pineda M, Tagliapietra D, and Turon X. 2015. Ongoing expansion of the worldwide invader Didemnum vexillum (Ascidiacea) in the 
476

477

478

479

480

481

482

483

484

485

486

487

488

489

490

491

492

493

494

495

496

497

498

Mediterranean Sea: high plasticity of its biological cycle promotes establishment in warm waters. Biological Invasions 17:2075-2085.

Pérez-Figueroa A. 2013. msap: a tool for the statistical analysis of methylation-sensitive amplified polymorphism data. Molecular ecology resources 13:522-527.

Pérez JE, Nirchio M, Alfonsi C, and Muñoz C. 2006. The biology of invasions: the genetic adaptation paradox. Biological Invasions 8:1115-1121.

Plongthongkum N, Diep DH, and Zhang K. 2014. Advances in the profiling of DNA modifications: cytosine methylation and beyond. Nature Reviews Genetics 15:647.

Prentis PJ, Wilson JRU, Dormontt EE, Richardson DM, and Lowe AJ. 2008. Adaptive evolution in invasive species. Trends in Plant Science 13:288-294.

$\mathrm{Pu} \mathrm{C}$, and Zhan A. 2017. Epigenetic divergence of key genes associated with water temperature and salinity in a highly invasive model ascidian. Biological Invasions:19:2015-2028.

Putnam HM, Davidson JM, and Gates RD. 2016. Ocean acidification influences host DNA methylation and phenotypic plasticity in environmentally susceptible corals. Evolutionary Applications 9:1165-1178.

Renborg E, Johannesson K, and Havenhand J. 2014. Variable salinity tolerance in ascidian larvae is primarily a plastic response to the parental environment. Evolutionary Ecology 28:561-572.

Reyna-Lopez G, Simpson J, and Ruiz-Herrera J. 1997. Differences in DNA methylation patterns are detectable during the dimorphic transition of fungi by amplification of restriction polymorphisms. Molecular and General Genetics MGG 253:703-710.

Rinkevich B, and Fidler AE. 2014. Initiating laboratory culturing of the invasive ascidian Didemnum vexillum. Management of Biological Invasions 5:55-62. 
499 Rocha RM, Castellano GC, and Freire CA. 2017. Physiological tolerance as a tool to support $500 \quad$ invasion risk assessment of tropical ascidians. Marine Ecology Progress Series 577:105$501 \quad 119$.

502 Rosner A, Moiseeva E, Rinkevich Y, Lapidot Z, and Rinkevich B. 2009. Vasa and the germ line $503 \quad$ lineage in a colonial urochordate. Developmental Biology 331:113-128.

504 Sakai AK, Allendorf FW, Holt JS, Lodge DM, Molofsky J, With KA, Baughman S, Cabin RJ, 505 Cohen JE, and Ellstrand NC. 2001. The population biology of invasive species. Annual $506 \quad$ Review of Ecology and Systematics 32:305-332.

507 Schneider CA, Rasband WS, and Eliceiri KW. 2012. NIH Image to ImageJ: 25 years of image $508 \quad$ analysis. Nature Methods 9:671.

509 Serafini L, Hann JB, Kültz D, and Tomanek L. 2011. The proteomic response of sea squirts 510 (genus Ciona) to acute heat stress: a global perspective on the thermal stability of proteins. Comparative Biochemistry and Physiology Part D: Genomics and Proteomics

513 Sokolova IM, Frederich M, Bagwe R, Lannig G, and Sukhotin AA. 2012. Energy homeostasis as an integrative tool for assessing limits of environmental stress tolerance in aquatic invertebrates. Marine Environmental Research 79:1-15.

Stefaniak L, Zhang H, Gittenberger A, Smith K, Holsinger K, Lin S, and Whitlatch RB. 2012. Determining the native region of the putatively invasive ascidian Didemnum vexillum Kott, 2002. Journal of Experimental Marine Biology and Ecology 422:64-71.

Tagliapietra D, Keppel E, Sigovini M, and Lambert G. 2012. First record of the colonial ascidian Didemnum vexillum Kott, 2002 in the Mediterranean: Lagoon of Venice (Italy). BioInvasions Records 1:247-254. 
522 Toop T, and Wheatly MG. 1993. Some behavioural and physiological responses of the ascidian 523 Styela plicata (Lesueur) during acclimation to low salinity. Marine \& Freshwater $524 \quad$ Behaviour \& Phy 24:33-44.

525 Varriale A, and Bernardi G. 2006. DNA methylation and body temperature in fishes. Gene $526 \quad 385: 111-121$.

527 Verhoeven KJF, and Preite V. 2014. Epigenetic variation in asexually reproducing organisms. $528 \quad$ Evolution 68:644-655.

529 Visser ME. 2008. Keeping up with a warming world; assessing the rate of adaptation to climate $530 \quad$ change. Proceedings of the Royal Society of London B: Biological Sciences 275:649-659.

531 Waterland RA, and Jirtle RL. 2003. Transposable elements: targets for early nutritional effects 532 on epigenetic gene regulation. Molecular and Cellular Biology 23:5293-5300.

533 Zerebecki RA, and Sorte CJB. 2011. Temperature tolerance and stress proteins as mechanisms of $534 \quad$ invasive species success. PLOS ONE 6:e14806.

535 Zhan A, Briski E, Bock DG, Ghabooli S, MacIsaac HJ 2015. Ascidians as models for studying 536 invasion success. Marine Biology 162:2449-2470.

537

538

539

540

541

542

543 
Table $\mathbf{1}$ (on next page)

Adapter and primer sequences.

Adapter and primer sequences used for MS-AFLP protocol. 


\begin{tabular}{ll}
\hline Adapters & Sequence 5'- 3' \\
\hline EcoRI-adapter F & 5'-CTC GTA GAC TGC GTA CC-3' \\
EcoRI-adapter R & 5'-AAT TGG TAC GCA GTC TAC-3' \\
HpaII and MspI-Adapter F & 5'-GAC GAT GAG TCT AGA A-3'' \\
HpaII and MspI-Adapter R & 5'-CGT TCT AGA CTC ATC-3' \\
Pre-selective primers & \\
\hline EcoRI-A & 5'-GAC TGC GTA CCA ATT CA-3' \\
HpaII and MspI -T & 5'-GAT GAG TCT AGA ACG GT-3' \\
Selective primers & \\
\hline EcoRI + AAG & 5'-GAC TGC GTA CCA ATT CAA G-3' \\
EcoRI + ACT & 5'-GAC TGC GTA CCA ATT CAC T-3' \\
HpaII MspI + TAC & 5'-6-FAM-GAT GAG TCT AGA ACG GTA C-3' \\
HpaII MspI + TCC & 5'-6-FAM-GAT GAG TCT AGA ACG GTC C-3' \\
\hline
\end{tabular}




\section{Table 2 (on next page)}

CCGG sites where methylation sensitive restriction enzymes (Hpall and Mspl) cleave (Yes) or do not cleave (No) to generate methylation dependent fragment patterns.

Both Mspl and Hpall recognise CCGG sites and cleave unmethylated CCGG sites (1/1), but Mspl cannot cleave when the outer cytosine is fully or hemimethylated ( $m$ ), and Hpall cannot cleave when the inner or outer cytosine is methylated on both strands. Cleaving by both enzymes is blocked when both cytosines are methylated. From this the methylation state of restriction sites can be scored (e.g., methylated ( $1 / 0$ or $0 / 1)$ unmethylated (1/1) and uninformative (0/0)). 


\begin{tabular}{|c|c|c|c|c|c|}
\hline & \multicolumn{2}{|c|}{ Restriction sites } & HpaII & Mspl & Fragment classification \\
\hline \multirow{2}{*}{ Type I } & 5'-CCGG & & Yes & Yes & Unmethylated \\
\hline & GGCC-5' & & & & $1 / 1$ \\
\hline \multirow[t]{2}{*}{ Type II } & 5'-mCCGG & $5^{\prime}-{ }^{m} C^{m} C G G$ & Yes & No & Hemimethylated \\
\hline & GGCC-5' & GGCC-5' & & & $1 / 0$ \\
\hline \multirow[t]{2}{*}{ Type III } & 5'-C ${ }^{\mathrm{m}} \mathrm{CGG}$ & & No & Yes & Internal cytosine methylation \\
\hline & $\mathrm{GG}^{\mathrm{m}} \mathrm{CC}-5^{\prime}$ & & & & $0 / 1$ \\
\hline \multirow[t]{2}{*}{ Type IV } & 5'-m C ${ }^{\mathrm{m}} \mathrm{CGG}$ & 5'-mCCGG & No & No & Uninformative \\
\hline & $\mathrm{GG}^{\mathrm{m}} \mathrm{C}^{\mathrm{m}} \mathrm{C}-5^{\prime}$ & $\mathrm{GGC}^{\mathrm{m}} \mathrm{C}-5^{\prime}$ & & & $0 / 0$ \\
\hline
\end{tabular}


Figure 1

Colony growth rates with increasing temperature.

Colony growth rates (mean growth per day, $\mathrm{mm} \pm 1$ s.e.) at 19,25 and $27^{\circ} \mathrm{C}$. Significant differences between treatments are denoted by different letters $(p<0.05$, Tukey's test HSD).

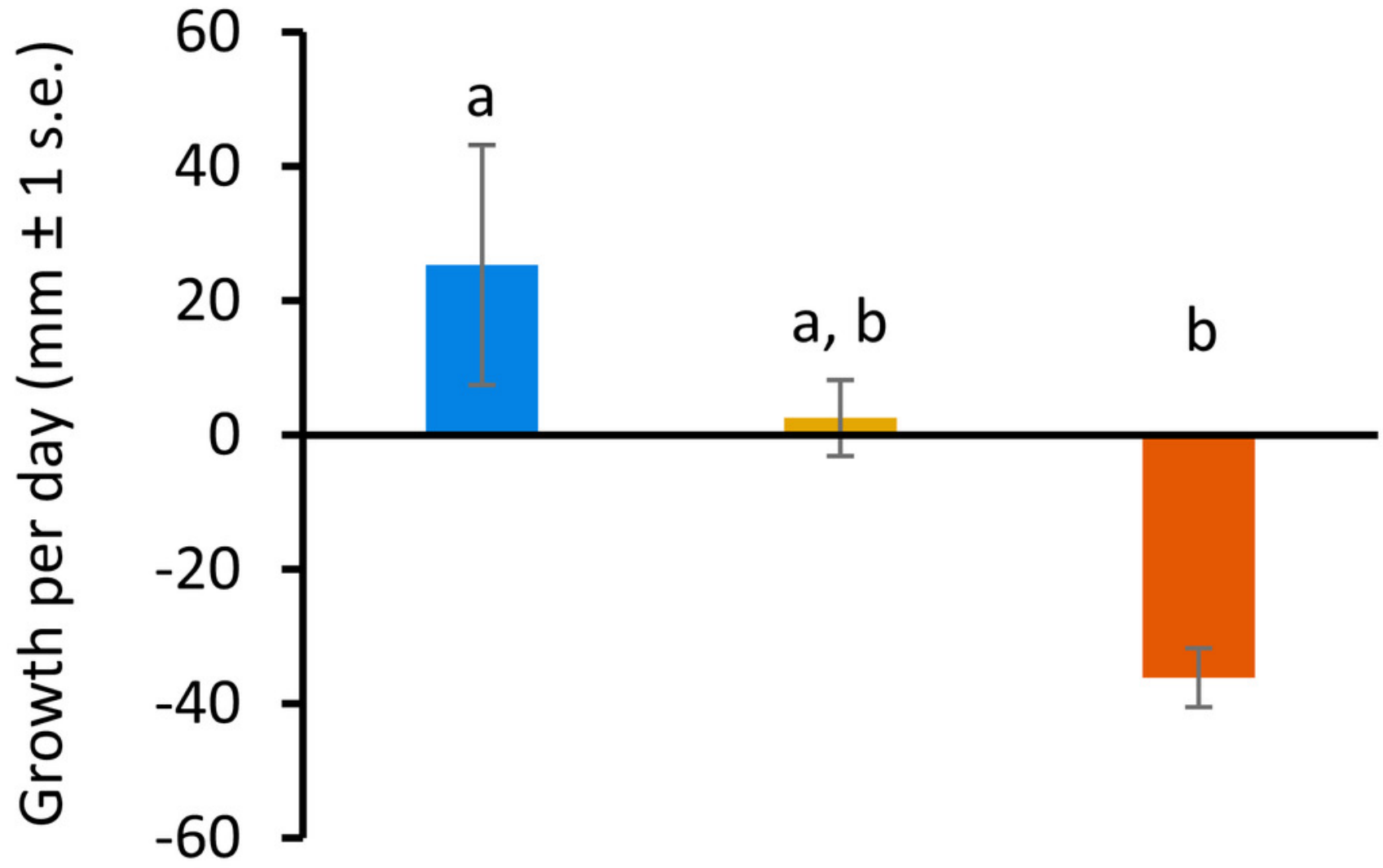

19

25

27

\section{Temperature $\left({ }^{\circ} \mathrm{C}\right)$}




\section{Figure 2}

\section{Principal Coordinate Analysis (PCOA) of methylation (MSL) differences between colonies exposed 19,25 and $27^{\circ} \mathrm{C}$.}

(A) between colonies at Time 0 (T0), prior to elevated temperature exposure (baseline methylation); (B) between colonies at Time 1 (T1) following a gradual temperature increase of $1^{\circ} \mathrm{C}$ per day until all treatment temperatures were reached: $19^{\circ} \mathrm{C}$ (control) $(\mathrm{n}=3), 25^{\circ} \mathrm{C}(\mathrm{n}$ $=3)$ and $27^{\circ} \mathrm{C}(\mathrm{n}=3) ;(\mathbf{C})$ at Time $2(\mathrm{~T} 2)^{*}$ after 3 days of elevated temperature exposure; (D) between sampling time points (T0, $\mathrm{T} 1, \mathrm{~T} 2)$ in colonies held at $19^{\circ} \mathrm{C}$; (E) $25^{\circ} \mathrm{C}$; (F) $27^{\circ} \mathrm{C}$. The first two coordinates ( $\mathrm{C} 1$ and $\mathrm{C} 2$ ) are shown with the percentage of variance explained by them. Points in each group cloud represent individuals from different groups. Temperature labels show the centroid for the points cloud in each group. Ellipses represent average dispersion of those points around their centre (Pérez-Figueroa 2013). AMOVA tests for significant differences in methylation (MSL) are shown in supplementary material, Tables S3 and S4. * represents significant difference $(p<0.05)$. 
A:

Time 0

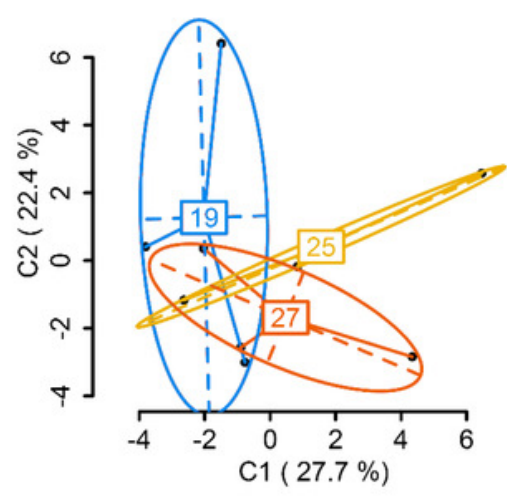

D:

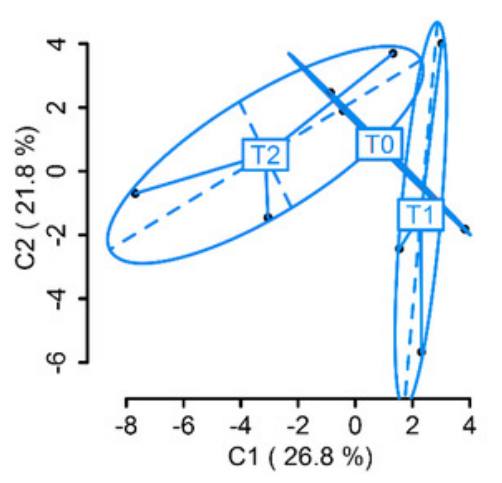

B:

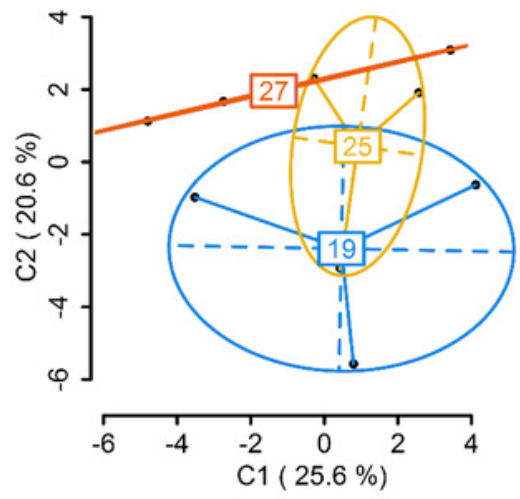

E:

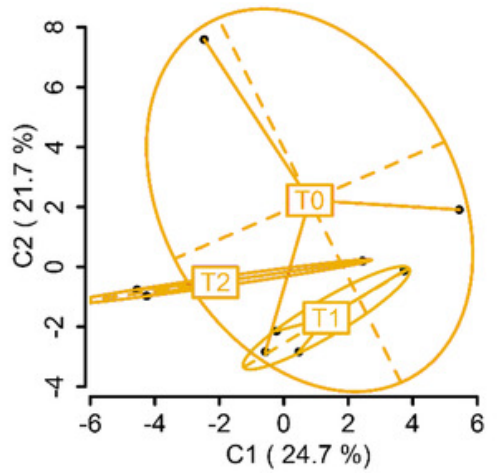

C:

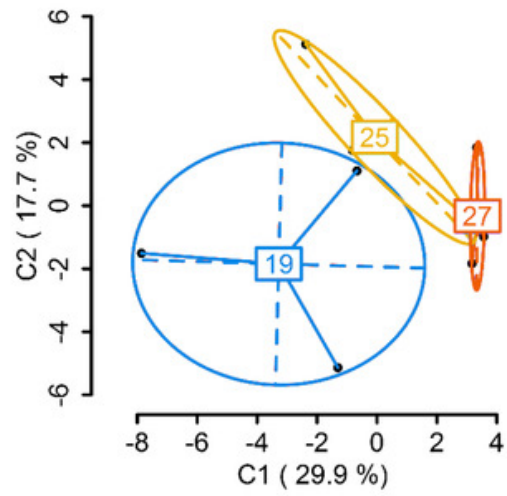

F:

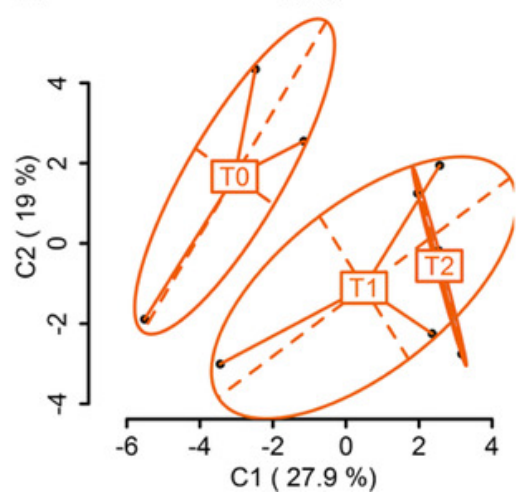


Figure 3

Colony growth rates with decreasing salinity.

Colony growth rates (mean growth per day, $\mathrm{mm} \pm 1$ s.e.) at $26,28,30,32$, and 34 PSU.

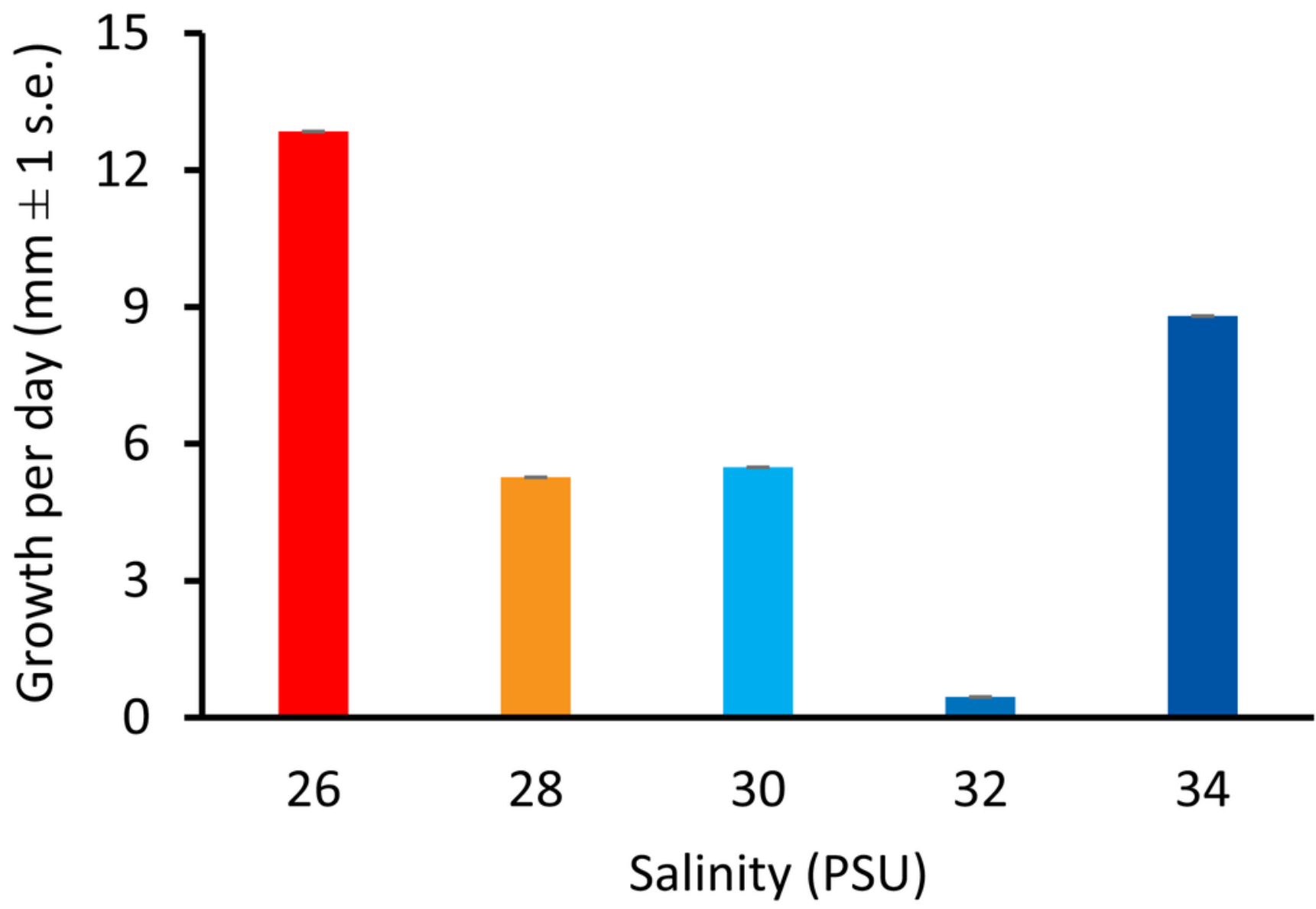




\section{Figure 4}

\section{Principal Coordinate Analysis (PCOA) of methylation (MSL) differences between colonies exposed to 34, 32, 30, 28 and 26 PSU.}

(A) between colonies at Time 0 (T0), prior to salinity treatment exposure (baseline methylation); (B) between colonies at Time 1 (T1) following a gradual salinity decrease of 1 PSU per day until all salinity treatments were reached: 34 PSU (control) $(n=3), 32$ PSU $(n=$ 3), 30 PSU ( $n=3), 28$ PSU ( $n=3)$ and 26 PSU ( $n=3)$; (C) at Time 2 (T2) after 3 days of decreased salinity exposure; (D) between sampling time points (T0, T1, T2) in colonies held at 26 PSU; (E) 28 PSU; (F) 30 PSU; (G) 32 PSU; (H) 34 PSU. The first two coordinates (C1 and C2) are shown with the percentage of variance explained by them. Points in each group cloud represent individuals from different groups. Labels show the centroid for the points cloud in each group. Ellipses represent average dispersion of those points around their centre (Pérez-Figueroa 2013). AMOVA tests for significant differences in methylation (MSL) are shown in supplementary material, Tables S6 and S7. No significant differences between groups were found. 
A:

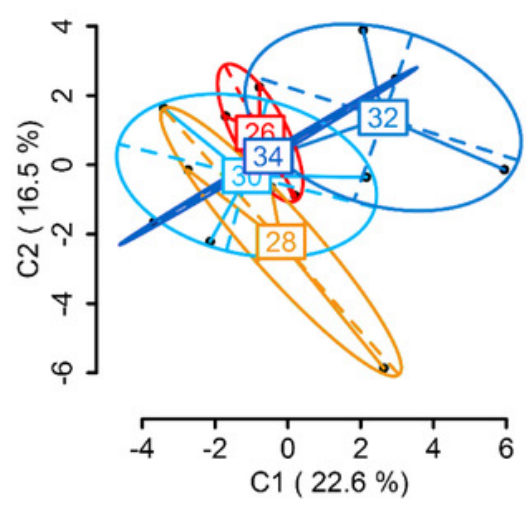

D:

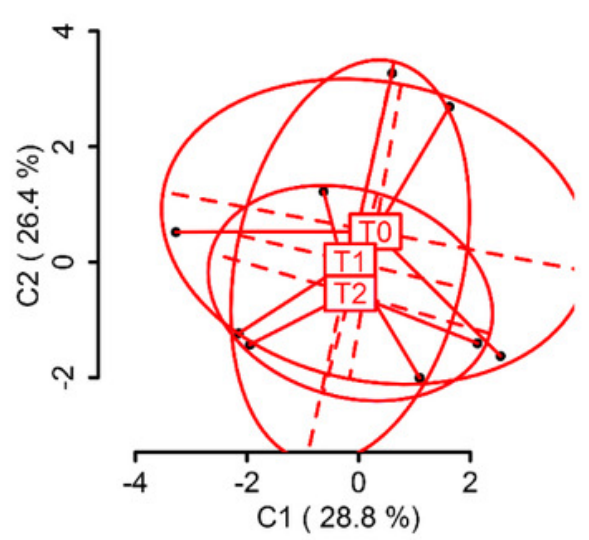

G:

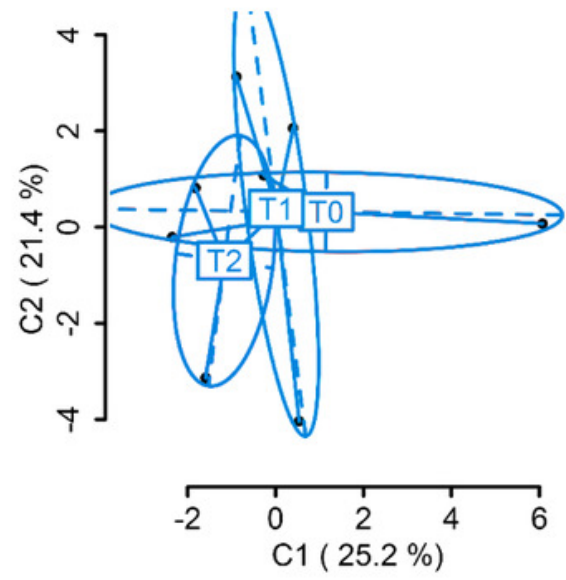

B:

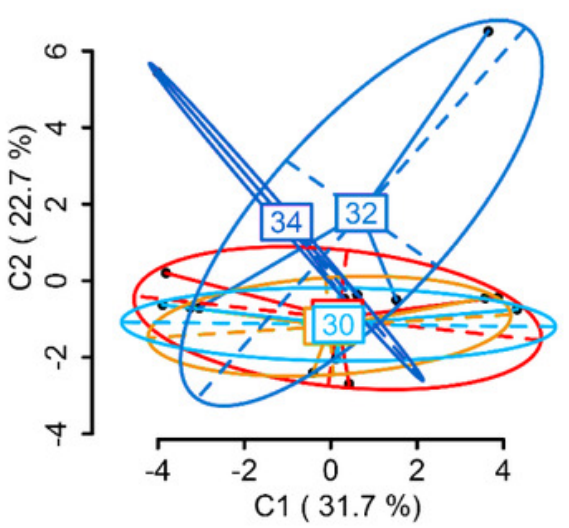

E:

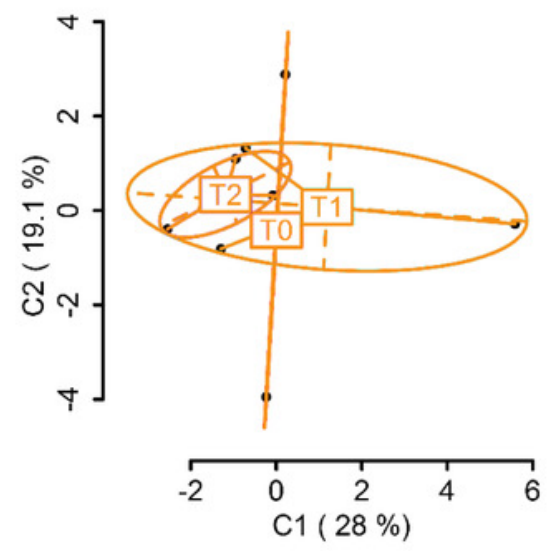

$\mathrm{H}$ :

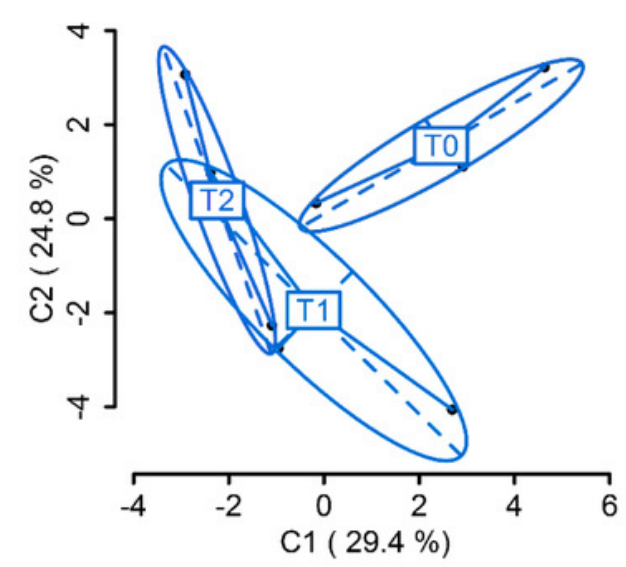

C:

Time 2

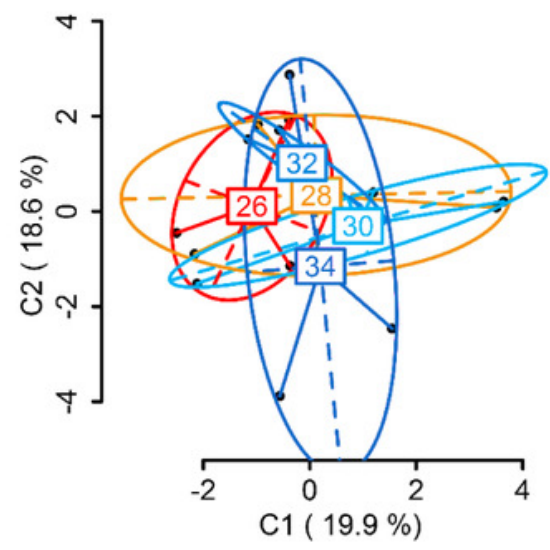

$F$ :

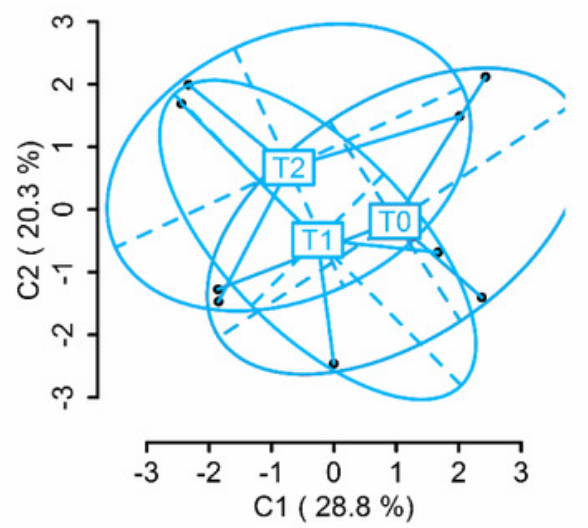

